\title{
ANALISIS RESPON KREDIT DAN PEMBIAYAAN INDUSTRI PERBANKAN DI INDONESIA
}

\author{
Mulia Amirullah ${ }^{1}$, Abrista Devi² \\ ${ }^{1}$ Sekolah Tinggi Ekonomi Islam Ar Risalah, Ciamis \\ ${ }^{2}$ Universitas Ibn Khaldun, Bogor \\ $\triangle$ mul.amirulloh@gmail.com \\ \abristasmart@gmail.com
}

\begin{abstract}
This study aims to measure the productive credit performance of conventional banks and profit-sharing financing for Islamic banks and analyze their responses to the shock of macroeconomic variables. In this study, the analysis method used is the Vector Auto-Regressive (VAR) / Vector Error Correction Model (VECM). The data observed in this study are monthly data from the period 2015 to 2019. The results showed that NPL (Non Performing Loan) was responding negatively to the shock of the productive credit, meanwhile NPF (Non Performing Financing) was responding positively to the shock of the profit-sharing financing. NPL have the most dominant contribution to the productive credit of conventional bank. Meanwhile, world oil prices are projected as the highest contribution to the profit-sharing financing for Islamic banks. Conventional bank productive credit affects inflation. The world crude oil price (OIP) affects the problematic financing of Islamic banks. The price of crude oil affects the exchange rate, and the exchange rate affects inflation.
\end{abstract}

Keywords : credit, financing, NPL/NPF, VECM

\section{LATAR BELAKANG}

Industri perbankan memiliki peran sangat penting bagi penggerak pertumbuhan ekonomi nasional. Babak baru perkembangan perbankan di Indonesia dimulai sejak Undang-Undang Republik Indonesia No 10 Tahun 1998 tentang perubahan atas UU No 7 Tahun 1992 tentang perbankan yang mengizinkan bank syariah menjalankan operasinya sebagai Bank Umum Syariah.

Tabel 1 Perkembangan Jumlah Bank Umum di Indonesia periode 2014-2019

\begin{tabular}{|c|c|c|}
\hline Periode & $\begin{array}{c}\text { Bank Umum } \\
\text { Konvensional }\end{array}$ & Bank Umum Syariah \\
\hline 2014 & 107 & 12 \\
\hline 2015 & 106 & 12 \\
\hline 2016 & 103 & 13 \\
\hline 2017 & 102 & 13 \\
\hline 2018 & 101 & 13 \\
\hline 2019 & 96 & 14 \\
\hline
\end{tabular}

Sumber: Statistik Perbankan Syariah, 2019 
Sebagai lembaga penghimpun dan penyalur dana masyarakat, ketersediaan kredit/pembiayaan perbankan memberi kemudahan bagi rumah tangga untuk berkonsumsi serta memungkinkan bagi sektor swasta berinvestasi yang tidak mampu dilakukannya dengan sumber daya sendiri. Penyaluran dana kepada masyarakat pada aset produktif khususnya akan memacu produktivitas sektor rill, akumulasi modal dan pertumbuhan output secara agregasi (Bencivenga \& Smith, 1991). Meskipun pertumbuhan perusahaan pembiayaan (multifinance) yang terbilang pesat, dominasi total kredit terhadap sektor swasta dari industri perbankan sejak periode $1990 \mathrm{~s} / \mathrm{d}$ 2010 masih terbilang cukup baik yakni sebesar 85\% (Utari et al., 2012).

Industri perbankan, sebagaimana perusahaan pada umumnya berusaha untuk menuai hasil (return) namun selalu dihadapkan dengan berbagai macam risiko. Salah satu risiko yang menerpa industri perbankan adalah risiko kredit. Bank dituntut lebih tanggap dan aktif dalam mendeteksi hal-hal yang membawa dampak kerugian sehingga dapat menekan laju tingkat kredit bermasalah.Pada bank konvensional kredit bermasalah dikenal dengan istilah NPL (Non Performing Loan), sedangkan kemacetan atau gagal bayar pada bank syariah disebut dengan NPF (Non Performing Financing).

Tingginya lonjakan kredit macet (NPL maupun NPF) merupakan salah satu indikator kegagalan industri perbankan dilihat dari stabilitas sistem keuangan, namun demikian kestabilan sistem keuangan perbankan juga bersumber dari guncangan makroekonomi seperti nilai tukar/kurs (Ascarya \& Yumanita, 2009). Secara meluas, profitabilitas perbankan dipengaruhi oleh variabel-variabel makroekonomi seperti inflasi, nilai tukar (kurs), tingkat suku bunga Bank Indonesia (BI rate) dan harga minyak mentah dunia(Widokartiko et al., 2016).

Penelitian ini untuk mengetahui dan menganalisa kredit bermasalah (NPL dan NPF) dan faktor-faktor dari makro ekonomi diantaranya inflasi, nilai kurs dan harga minyak mentah dunia yang menggambarkan hubungannya terhadap kredit produktif Bank Umum Konvensional (BUK) dan pembiayaan produktif Bank Umum Syariah. Analisa ini dilakukan sebagai gambaran umum manajerial perbankan, khususnya mengantisipasi risiko masa depan bank umum (BUK dan BUS) dengan segala kemungkinan yang akan terjadi.

\section{TEORI DAN METODE}

\subsection{Kredit dan Pembiayaan Perbankan}

Dalam Undang Undang Nomor 10 Tahun 1998 Pasal 1 dinyatakan bahwa kredit adalah penyediaan uang atau tagihan yang dapat dipersamakan dengan itu, berdasarkan persetujuan atau kesepakatan pinjam-meminjam antara bank dengan pihak lain yang mewajibkan pihak peminjam untuk melunasi utangnya setelah jangka waktu tertentu dengan pemberian bunga, sedangkan pembiayaan berdasarkan Prinsip Syariah adalah penyediaan uang atau tagihan yang dipersamakan dengan itu berdasarkan persetujuan atau kesepakatan antara bank dengan pihak lain yang mewajibkan pihak yang dibiayai untuk mengembalikan uang atau tagihan tersebut setelah jangka waktu tertentu dengan imbalan atau bagi hasil.

Jenis kredit perbankan dilihat dari tujuan penggunaannya yang terdiri dari kredit konsumtif dan kredit produktif. Kredit konsumtif merupakan pinjaman kepada masyarakat yang akan habis digunakan atau semua akan terpakai untuk memenuhi kebutuhan pribadi. Adapun kredit produktif digunakan untuk peningkatkan usaha, produksi maupun investasi yang umumnya dibagi menjadi dua 
yaitu kredit modal kerja dan kredit investasi (Meitasari, 2014). Adapun perbankan syariah, penyaluran dana kepada masyarakat lebih luas dikenal dengan pembiayaan. Pembiayaan bank syariah, dari sisi tujuan penggunannya terdiri pembiayaan bagi hasil dan pembiayaan non bagi hasil.Pembiayaan dengan prinsip bagi hasil berdasar kesepakatan ulama dalam bentuk mudharabah dan musyarakah. Salah satu langkah kebijakan yang dilakukan Bank Indonesia untuk menciptakan lingkungan yang kondusif, efisien, kompetitif dan hati-hati bagi industri perbankan syariah adalah mendukung sektor riil melalui pembiayaan bagi hasil (Yumanita \& Ascarya, 2005)

Bank Indonesia selaku regulator menetapkan penilaian tingkat kesehatan bank umum, salah satu faktor untuk menilai kinerja bank adalah risiko kredit (Bank Indonesia, 2011). Kolektibilitas kredit menentukan kualitas suatu kredit itu sendiri, lancar dan tersendatnya pembayaran pokok pinjaman dan bunga ditinjau dari kondisi usaha debitur. Dengan demikian, kolektabilitas kredit dikategorikan lancar, kurang lancar, diragukan dan macet (Ginting, 2017).

Kredit bermasalah (NPL) Bank Konvensional dan Pembiayaan bermasalah (NPF) Bank Syariah dipengaruhi oleh faktor internal dan eksternal. Dari sisi internal diantaranya penyimpangan pelaksanaan prosedur perkreditan, lemahnya system administrasi dan pengawasan kredit serta itikad kurang baik dari pihak bank. Sedangkan dari eksternal diantaranya menurunnya kegiatan ekonomi, tingginya suku bunga, kegagalan usaha debitur serta bencana maupun musibah yang menimpa debitur(Yulizar D Sanrego, 2014).

\subsection{Makroekonomi dan Penyaluran Kredit Perbankan}

Beberapa kajian sebelumnya menunjukkan bahwa ada korelasi antara kondisi makroekonomi suatu Negara dengan kinerja industri perbankan. Hasil kajian (Keeton \& Morris, 1987) menyatakan bahwa salah satu faktor utama kredit bermasalah (NPL) ditunjukkan oleh buruknya kondisi perekonomian lokal. Begitu pun yang dikemukakan oleh (Festić \& Bekocombining double acute accent, 2008) bahwa guncangan makroekonomi menjadi salah satu faktor yang menyebabkan kinerja perbankan menurun dengan meningkatnya Non Performing Loan. Kondisi demikian juga diduga berlaku pada pembiayaan bermasalah bank umum syariah. Oleh karenanya, regulator menetapkan rasio NPL (Non Performing Loan) total kredit secara bruto (gross) kurang dari 5\% (Bank Indonesia, 2015).

Dinyatakan oleh (Widokartiko et al., 2016), profitabilitas perbankan konvensional dipengaruhi oleh BI Rate, nilai tukar rupiah dan NPL namun profitabilitas perbankan syariah tidak dipengaruhi oleh variabel makroekonomi maupun internal. Respon dari profitabilitas perbankan syariah terhadap pergerakan kurs dan inflasi lebih cepat stabil, akan tetapi gejolak makroekonomi yang terjadi berdampak positif terhadap profitabilitas perbankan konvensional.

\subsection{Metode Penelitian}


Penelitian ini menggunakan data sekunder dalam bentuk time series, data yang diamati berupa data bulanan mulai kurun waktu 2015 sampai dengan 2019. Variabel makroekonomi diantaranya inflasi, nilai tukar rupiah/kurs, dan harga minyak mentah dunia. Sedangkan variabel internal industri perbankan diantaranya kredit produktif bank umum konvensional, pembiayaan bagi hasil bank umum syariah serta kredit/pembaiayaan bermasalah bank umum (NPL dan NPF). Jenis data dan variabel dalam penelitian ini dijelasakan pada table 2 .

Tabel 2 Jenis data dan variabel yang digunakan dalam penelitian

\begin{tabular}{lcl}
\hline \multicolumn{1}{c}{ Jenis Data } & Variabel & \multicolumn{1}{c}{ Sumber } \\
\hline $\begin{array}{l}\text { Kredit produktif bank } \\
\text { umum konvensional }\end{array}$ & KP & Otoritas Jasa Keuangan \\
$\begin{array}{l}\text { Pembiayaan bagi } \\
\text { hasil bank umum }\end{array}$ & PBH & Otoritas Jasa Keuangan \\
syariah & & \\
Kredit bermasalah & NPL/NPF & Otoritas Jasa Keuangan \\
Inflasi & INF & Bank Indonesia \\
Nilai tukar & Kurs & Bank Indonesia \\
Harga minyak dunia & OIP & $\begin{array}{l}\text { West } \\
\text { Intermediate }\end{array}$ \\
\hline
\end{tabular}

Alat analisa yang digunakan pada penelitian ini adalah VAR/VECM, mengingat data bersifat time series multivariate. Metode Vector Autoregression atau VAR adalah pendekatan non-struktural yang menggambarkan hubungan yang "saling menyebabkan" (kausalistis) antar variabel dalam sistem. Untuk tetap mendapatkan hubungan jangka panjang, model VAR akan dimodifikasi menjadi model koreksi kesalahan Vector Error Correction Model (VECM), jika terdapat kointegrasi dalam model(Ascarya, 2009). Adapun spesifikasi model VECM yang dibentuk dalam penelitian ini sebagai berikut:

$$
\Delta x_{t}=\pi_{0}+\pi x_{1}+\pi_{1} \Delta x_{t-1}+x_{2} \Delta x_{t-2}+\ldots+\pi_{p} \Delta x_{t-p}+\varepsilon_{t}
$$

Keterangan:

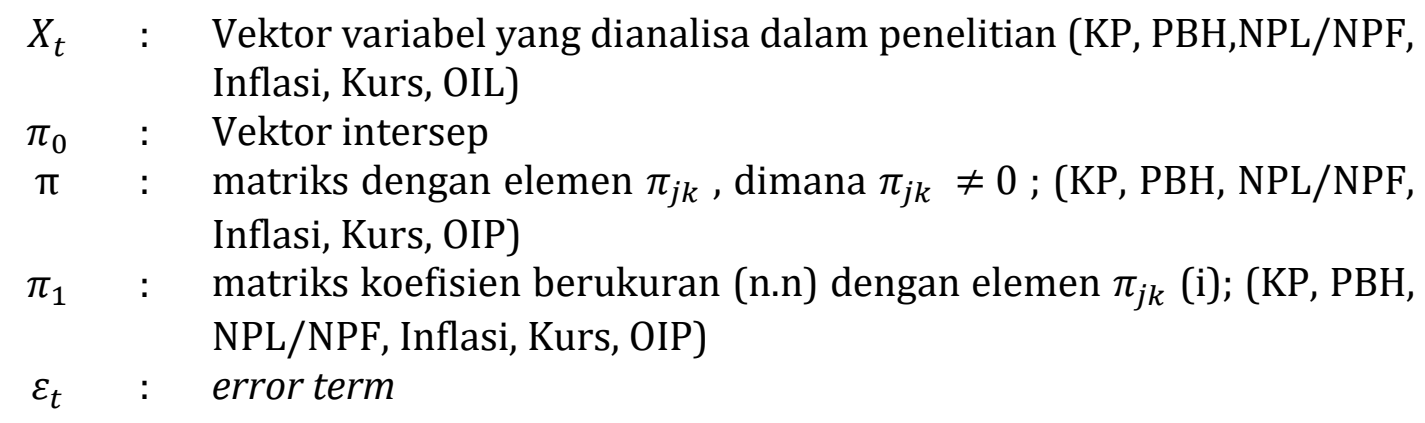

Selanjutnya dilakukan Impuls Respon Function (IRF) serta Variance Decomposition untuk menganalisa efek dari pengaruh tekanan dan guncangan dari variabel yang ditentukan dalam penelitian(Basuki, 2018).

\section{HASIL DAN PEMBAHASAN}




\subsection{Pengujian Granger Causality}

Uji kausalitas grangerdilakukan untuk mengetahui hubungan kausalitas (sebabakibat) dua arah antar variabel yang diamati dalam penelitian, pada uji granger causality ini menggunakan taraf nyata 0,05. Dari hasil uji dinyakatakan bahwa kredit produktif (KP) bank umum konvensional berpengaruh terhadap inflasi (hubungan searah), sedangkan harga minyak dunia (OIP) berpengaruh terhadapNon Performing Financing (NPF) bank umum syariah (hubungan searah). Variabel kurs berpengaruh terhadap inflasi dan variabel OIP berpengaruh terhadap kurs (hubungan searah).

Hasil uji kausalitas menyatakan bahwa kredit produktif perbankan konvensional mempengaruhi gejolak tingkat inflasi di Indonesia, hal ini disebabkan suku bunga kredit merupakan "harga" dari kredit perbankan itu sendiri. Suku bunga (BI rate) dipengaruhi dari berbagai macam faktor diantaranya nilai tukar, inflasi dan juga harga minyak dunia. Sedangkan harga minyak dunia berpengaruh terhadap pembiayaan bermasalah (NPF) bank umum syariah. Guncangan harga minyak dunia berdampak langsung pada kenaikan harga bahan bakar minyak (BBM), dengan naiknya BBM memicu kenaikan ongkos/biaya produksi khususnya pada sektor produktif/riil di Indonesia. Hal ini sejalan dengan penelitian (Addury, 2018) menunjukkan bahwa harga minyak dunia berpotensi memicu tingkat gagal bayar (NPF) dan risiko likuiditas perbankan syariah di Indonesia.

\subsection{Impulse Response Function (IRF)}

a) Respon NPL/NPF terhadap Kredit Produktif/Pembiayaan Bagi Hasil

Gejolak NPLdirespon fluktuatif (negatif dan positif) dan menjadi guncangan besar oleh Kredit Produktif bank konvensional. Namun pada periode 30 hingga proyeksi 5 tahun ke depan ( 60 bulan) guncangan tersebut direspon negatif oleh kredit produktif dan relatif stabil. Demikian pula yang terjadi pada bank umum syariah, pembiayaan bermasalah direspon negatif juga positif serta cukup terguncang terhadap pembiayaan bagi hasil. Akan tetapi, sejak periode akhir yakni 45 bulan dengan proyeksi 60 bulan direspon positif dan cenderung stabil.

Dari hasil IRF ditunjukkan bahwa tingkat pembiayaan/kredit bermasalah yang menjadi salah satu indikator kinerja industri perbankan sangat responsif terhadap kredit bank umum konvensional dan pembiayaan bank umum syariah di Indonesia. Pada pembiayaan bagi hasil BUS, NPF menjadi perhatian khusus bagi pelaku industri dikarenakan direspon positif sejak periode 30 sampai dengan akhir. Respon positif ini menunjukkan pembiayaan bagi hasil selalu dibayangi oleh NPF yang mengindikasikan bahwa sektor riil mudah terpengaruh oleh faktorfaktor makroekonomi. Meskipun demikian, porsi NPF perbankan syariah masih didominasi oleh pembiayaan non bagi hasil.

Tabel 3Pembiayaan dan NPF berdasarkan Jenis Akad Bank Umum Syariah dalam miliar Rupiah

\begin{tabular}{|l|c|c|c|c|c|c|c|c|}
\hline \multirow{2}{*}{$\begin{array}{c}\text { Jenis } \\
\text { pembiayaan }\end{array}$} & \multicolumn{2}{|c|}{$\mathbf{2 0 1 6}$} & \multicolumn{2}{c|}{$\mathbf{2 0 1 7}$} & \multicolumn{2}{c|}{$\mathbf{2 0 1 8}$} & \multicolumn{2}{c|}{$\mathbf{2 0 1 9}$} \\
\cline { 2 - 8 } & NPF & $\mathbf{\%}$ & NPF & \% & NPF & \% & NPF & \% \\
\hline $\begin{array}{l}\text { Pembiayaan Bagi } \\
\text { Hasil }\end{array}$ & 2.572 & 32,83 & 3.541 & 39,22 & 2673 & 40,52 & 2.860 & 39,38 \\
\hline
\end{tabular}




\begin{tabular}{|l|c|c|c|c|c|c|c|c|}
$\begin{array}{l}\text { (Mudharabah dan } \\
\text { Musyarakah) }\end{array}$ & & & & & & & & \\
$\begin{array}{l}\text { Piutang } \\
\text { (Murabahah, } \\
\text { Qardh dan } \\
\text { Istishna) }\end{array}$ & 5.245 & 66,95 & 5.459 & 60,46 & 3.804 & 57,67 & 4.127 & 56,83 \\
\hline $\begin{array}{l}\text { Pembiayaan } \\
\text { Sewa/Ijarah } \\
\text { Sindikasi, } \\
\text { Channeling, } \\
\text { Executing dan } \\
\text { Sewa lainnya) }\end{array}$ & 17 & 0,22 & 29 & 0,32 & 119 & 1,80 & 275 & 3,79 \\
\hline Salam & - & - & - & - & - & - & - & - \\
\hline \multicolumn{1}{|c|}{ T0TAL } & $\mathbf{7 . 8 3 4}$ & $\mathbf{1 0 0}$ & $\mathbf{9 . 0 2 9}$ & $\mathbf{1 0 0}$ & $\mathbf{6 . 5 9 6}$ & $\mathbf{1 0 0}$ & $\mathbf{7 . 2 6 2}$ & $\mathbf{1 0 0}$ \\
\hline
\end{tabular}

Sumber: Statistik Perbankan Syariah OJK (data diolah, 2020)

b) Respon Inflasi terhadap Kredit Produktif/Pembiayaan Bagi Hasil

Gunjangan inflasi yang terjadi direspon berbeda oleh kredit BUK dan pembiayaan BUS. Kredit produktif Bank Umum Konvensional merespon inflasi secara fluktuatif di awal-awal periode, namun sejak periode 18 hingga akhir direspon negatif dan relatif stabil.Inflasi menunjukkan kondisi naiknya hargaharga barang pada periode tertentu. Kondisi ini disebabkan oleh tingginyademand masyarakat yang juga berarti jumlah uang yang beredar di masyarakat meningkat. Disinilah andil Bank Sentral sebagai otoritas moneter, Bank Sentral (BI) akan menaikkan suku bunga kredit untuk menekan jumlah uang beredar. Begitu pun sebaliknya, untuk meningkatkan perekonomian Bank Sentral akan menurunkan suku bunga sehingga penyaluran kredit kepada masyarakat meningkat dan demand masyarakat kembali tumbuh. Hasil ini sejalan dengan kajian (Yudi Setiawan \& Karsinah, 2018)bahwa Bank Sentral melakukan kebijakan ekspansi dengan cara menurunkan suku bunga SBI dalam rangka menumbuhkan perekonomian.

Guncangan inflasi direspon positif oleh pembiayaan bagi hasi BUS, meskipun di periode awal berfluktuasi (negatif dan positif) sampai dengan periode 30 relatif positif dan stabil. Kondisi ini menandakan bahwa kenaikan harga-harga barang dan tingginya pertumbuhan ekonomi tidak mempengaruhi penyaluran pembiayaan bagi hasil oleh bank syariah.Hasil ini selaras dengan kajian (Ichsan, 2017)yang menyatakan bahwa pembiayaan mudharabah atau bagi hasil bank syariah merespon positif terhadap guncangan inflasi dari awal periode hingga akhir periode dan mulai stabil sejak periode 11 bulan. Dalam perpsektif Islam, inflasi memang tidak dapat dihindari namun tetap bisa dikontrol.Akan tetapi untuk meredam laju inflasi bukan dengan interest rate, melainkan diantaranya dengan pelarangan melakukan spekulasi, konsumsi berlebihan, dan penimbunan barang (Awaluddin, 2017).

c) Respon Kurs terhadap Kredit Produktif/Pembiayaan Bagi Hasil 
Guncangan kurs direspon fluktuatif oleh kredit produktif bank konvensional dan relatif stabil sejak periode 25 hingga akhir. Berbeda halnya dengan bank umum syariah (BUS), guncangan kurs direspon negatif terhadap pembiayaan bagi hasil. Pembiayaan bagi hasil yang disalurkan pada sektor riil serta dianutnya konsep Profit and Loss Sharing pada bank syariah berdampak pada turunnya porsi pembiayaan akibat adanya guncangan kurs yang pada akhirnya berimbas pada penurunan output serta stabilitasi perbankan dan melemahnya stabilitas perbankan syariah. Kondisi ini sesuai sebagaimana dinyatakan oleh (Afifah et al., 2019)bahwa guncangan nilai tukar turut serta melemahkan stabilitas perbankan syariah di Indonesia.

Response to Cholesky One S.D. (d.f. adjusted) Innovations

Response of $\mathrm{D}(\mathrm{KP})$ to $\mathrm{D}(\mathrm{NPL})$

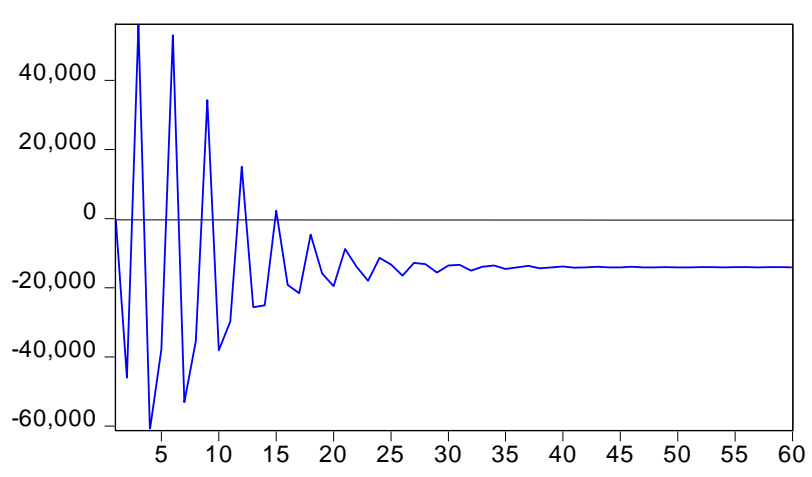

Response of $\mathrm{D}(\mathrm{KP})$ to $\mathrm{D}(\mathrm{KURS})$

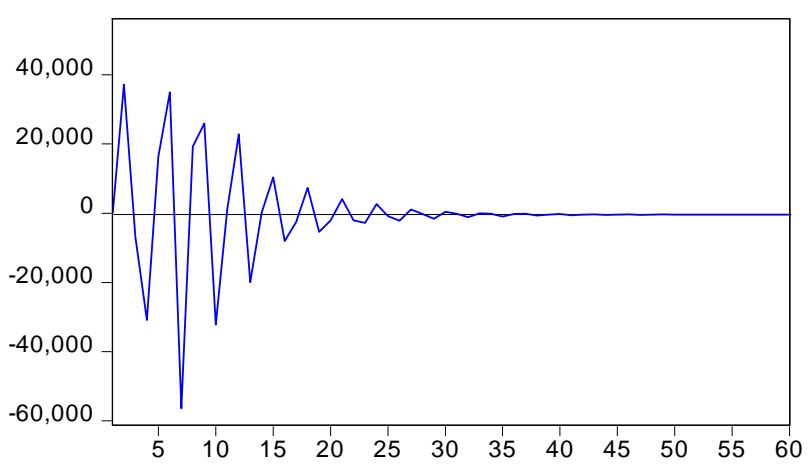

Response of $\mathrm{D}(\mathrm{KP})$ to $\mathrm{D}(\mathrm{INF})$

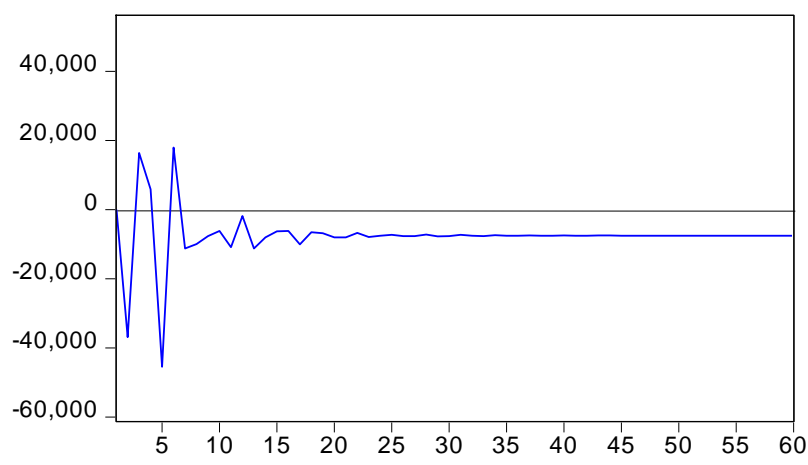

Response of $\mathrm{D}(\mathrm{KP})$ to $\mathrm{D}(\mathrm{OIP})$

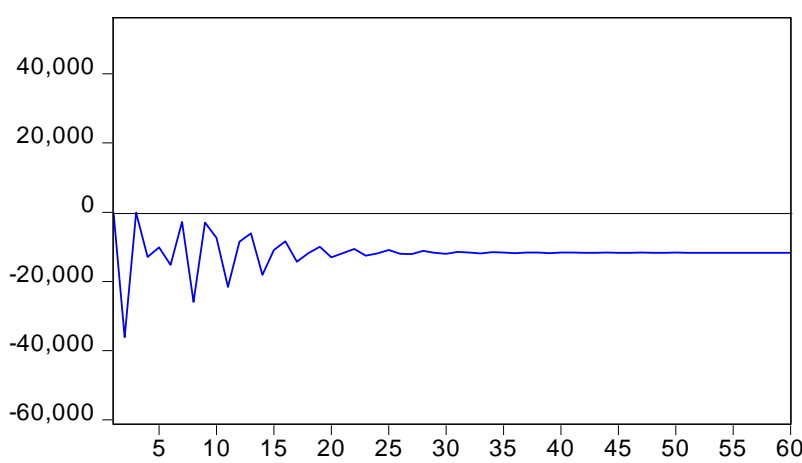

Gambar 1:IRF Model Kredit Produktif Bank Umum Konvensional

d) Respon Harga Minyak terhadap Kredit Produktif/Pembiayaan Bagi Hasil

Guncangan harga minyak dunia direspon negatif oleh kredit produktif BUK dan direspon fluktuatif diawal-awal periode oleh pembiayaan bagi hasil BUS serta negatif sejak periode 21 hingga akhir. Keadaan stabil juga lebih cepat dicapai oleh bank konvensional daripada bank syariah. Guncangan harga minyak dunia (OIP) menjadi salah satu faktor pendongkrak laju inflasi di Indonesia. Dengan naikknya tingkat inflasi akan menaikkan tingkat bunga kredit perbankan, dimana kondisi tersebut akan menurunkan tingkat kredit produktif bank konvensional pada 
masyarakat.Hal senada juga diungkapkan oleh (Khaliq, 2017) bahwa penurunan produksi industri, terdepresiasinya nilai tukar riil, kenaikan laju inflasi dan tingkat bunga domestik serta menurunnya harga aset diakibatkan oleh guncangan harga minyak dunia.

Guncangan OIP begitu sangat berdampak pada kinerja pembiayaan bagi hasil BUS. Kenaikan harga minyak berdampak langsung pada kenaikan harga-harga komoditi yang membuat menurunnya kinerja sektor riil tanpa dibarengi dengan peningkatan daya beli (konsumsi) masyarakat. Singkatnya, harga minyak dunia berperan atas berkurangnya saluran pembiayaan bagi hasil kepada sektor riil. Meskipun demikian, guncangan harga minyak masih direspon positif terhadap profitabilitas bank syariah (Widokartiko et al., 2016).

Response to Cholesky One S.D. (d.f. adjusted) Innovations

Response of $\mathrm{D}(\mathrm{PBH})$ to $\mathrm{D}(\mathrm{NPF})$

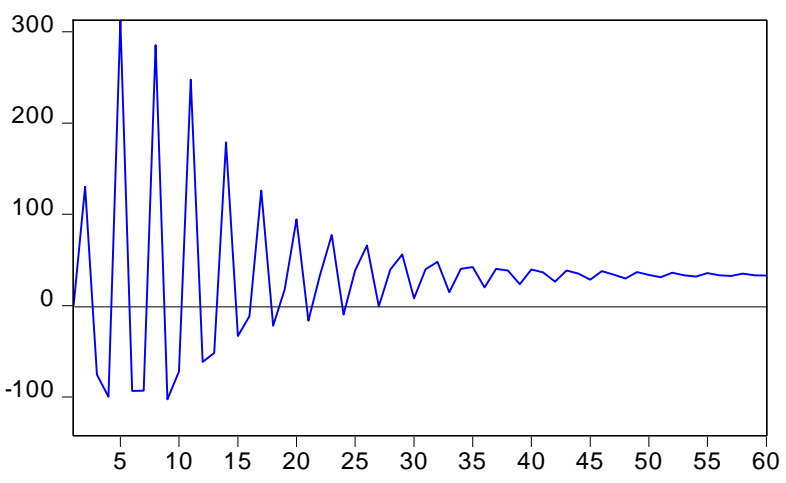

Response of $\mathrm{D}(\mathrm{PBH})$ to $\mathrm{D}(\mathrm{KURS})$

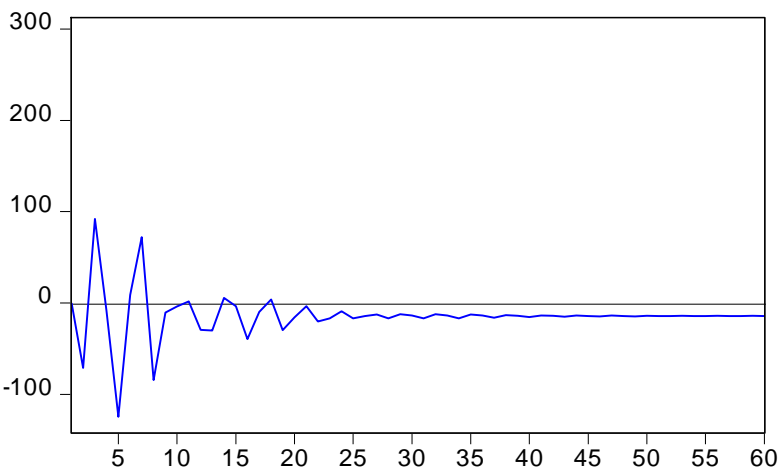

Response of $\mathrm{D}(\mathrm{PBH})$ to $\mathrm{D}(\mathrm{INF})$
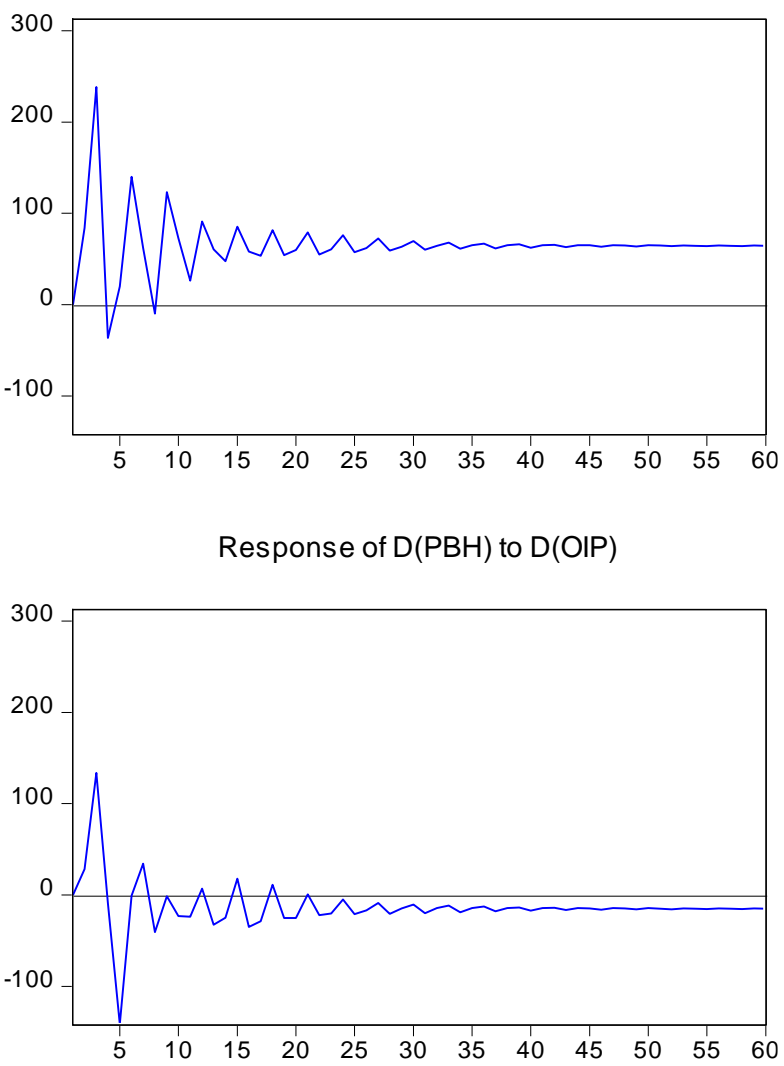

Gambar 2:IRF Model Pembiayaan Bagi Hasil Bank Umum Syariah

\subsection{Forecast Error Variance Decomposition (FEVD)}

Analisis selanjutnya yakni Forecast Error Variance Decomposition (FEVD), berfungsi untuk memprediksi kontribusi setiap variabel terhadap guncangan atau perubahan variabel tertentu(Ascarya, 2009). Pada gambar 3 prediksi kontribusi NPL bank konvensional adalah paling dominan selain kredit produktif itu sendiri, sedangkan variabel makro ekonomi inflasi, kurs dan harga minyak berkontribusi lebih rendah. Kontribusi NPL yang mendominasi kredit produktif dibanding variabel makro 
ekonomi, mengindikasikan bank umum konvensional berupaya selektif dalam menyalurkan kreditnya disertai dengan mempertimbangkan tingkat bunga perbankan yang merujuk BI rate. Hasil kajian (Aviliani et al., 2015) menunjukkan guncangan BI rate lebih dirasakan oleh kredit perbankan konvensional sedangkan NPL terguncang oleh tekanan nilai kurs. Dengan demikian, andil interest begitu besar dan sangat kuat pengaruhnya terhadap kinerja kredit perbankan konvensional.

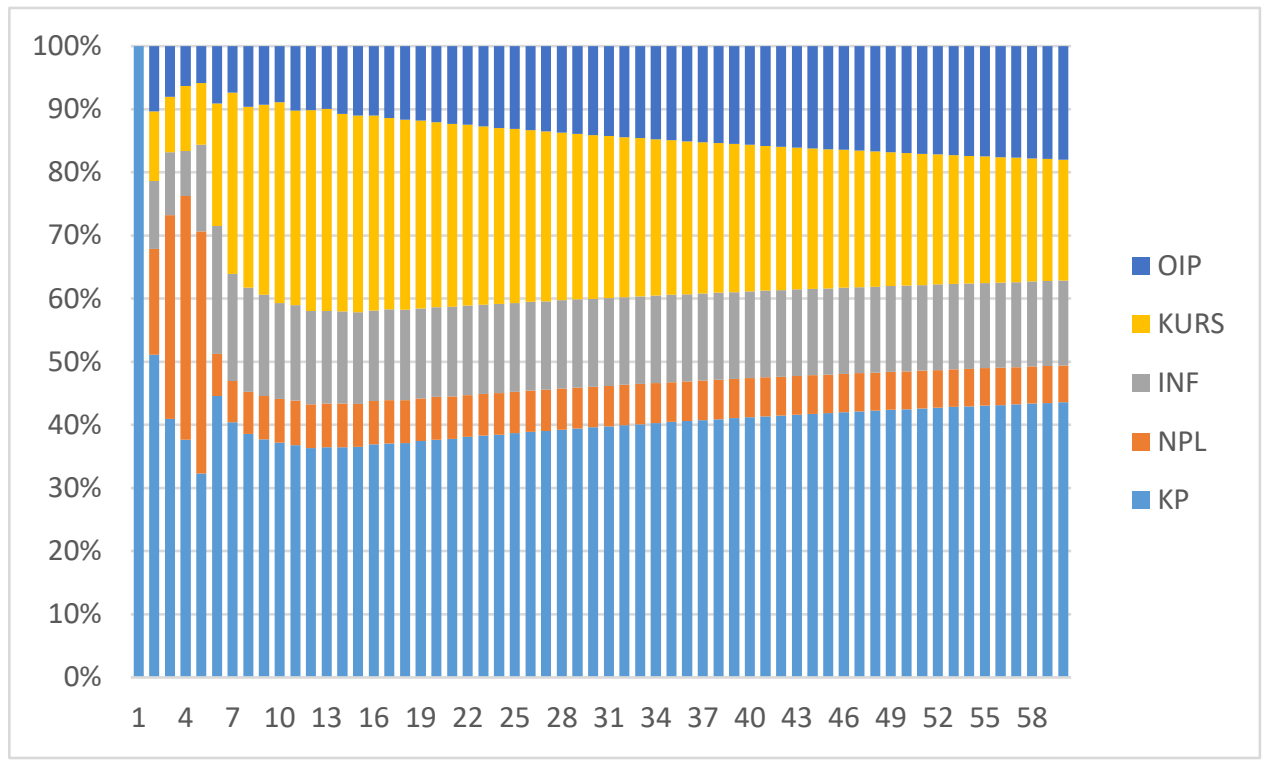

Gambar 3:FEVD Kredit Bank Umum Konvensional

Berbeda dengan perilaku kredit bank umum konvensional, harga minyak mentah diprediksi berkontribusi paling dominan terhadap pembiayaan bagi hasil bank umum. Yang kedua adalah inflasi, ketiga yakni nilai kurs dan terakhir adalah kinerja internal pembiayaan bermasalah atau NPF. Guncangan OIP berkontribusi besar terhadap pembiayaan bagi hasil BUS, kondisi demikian disebabkan penyaluran pembiayaannya mengarah pada sektor riil. Naiknya harga minyak mentah dunia mengakibatkan naiknya harga-harga komoditi tertentu yang pada akhirnya mempengaruhi pertumbuhan ekonomi Indonesia. Selain berpengaruh pada pertumbuhan ekonomi, guncangan OIP juga mempengaruhi pada jumlah uang beredar. Akibat guncangan harga minyak akan membentuk titik keseimbangan baru yang posisinya di atas keseimbangan awal(Andre \& Nasrudin, 2019). Sedangkan guncangan NPF berkontribusi paling rendah terhadap pembiayaan bagi hasil (berbanding terbalik dengan NPL bank umum konvensional). 


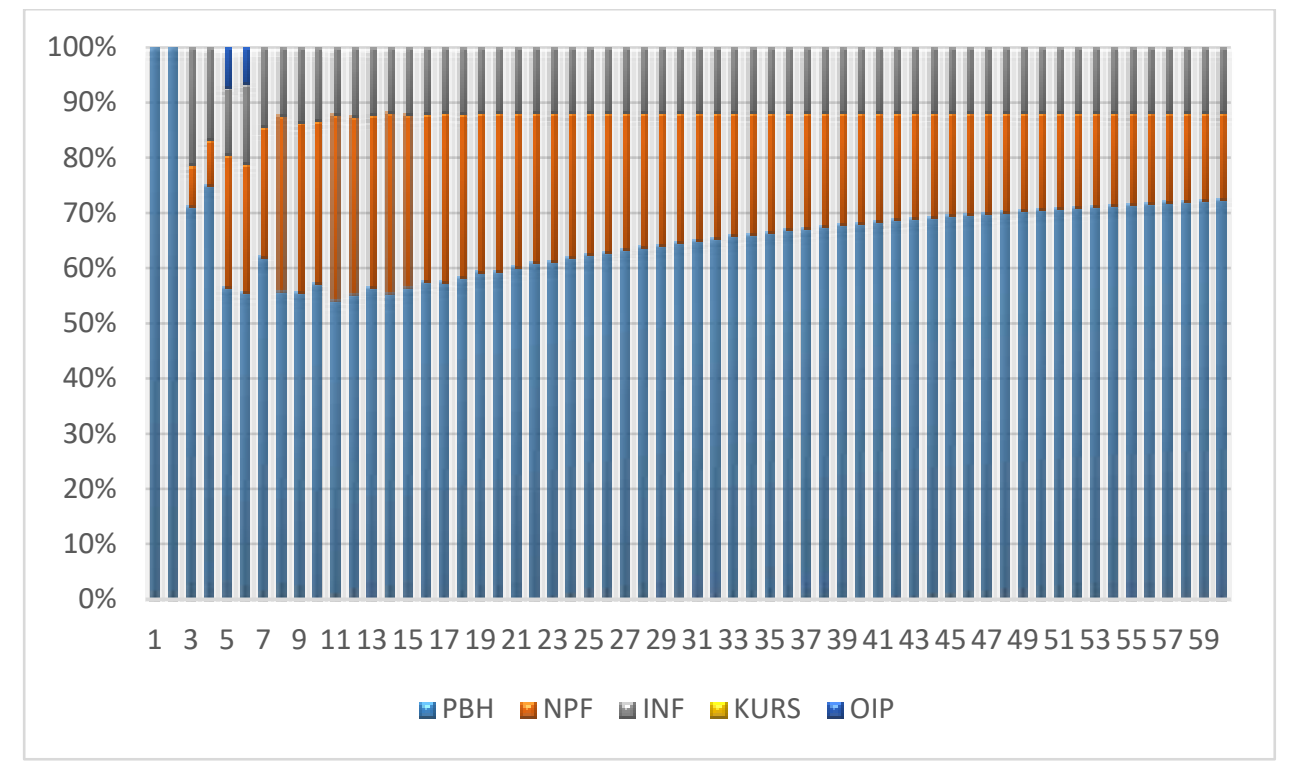

Gambar 4: FEVD Pembiayaan Bank Umum Syariah

\section{PENUTUP}

Berdasarkan hasil penelitian yang telah dianalisa, maka terdapat beberapa kesimpulan yangd dapat peneliti ambil. Ketika terjadi guncangan pada variabel NPL, maka Kredit Produktif bank konvensional merespon fluktuatif dalam jangka pendek, namun stabil negative dalam jangka panjang. Ketika terjadi guncangan pada variabel NPF, maka pembiayaan bagi hasil pada bank syariah merespon fluktuatif dalam jangka pendek, namun stabil positif dalam jangka panjang. Ketika terjadi guncangan pada variabel inflasi, maka Kredit Produktif bank konvensional merespon fluktuatif dalam jangka pendek, namun stabil negative dalam jangka panjang. Ketika terjadi guncangan pada variabel inflasi, maka pembiayaan bagi hasil pada bank syariah merespon fluktuatif dalam jangka pendek, namun stabil positif dalam jangka panjang. Ketika terjadi guncangan pada variabel kurs, maka Kredit Produktif bank konvensional merespon fluktuatif dalam jangka pendek, namun stabil positif dalam jangka panjang. Ketika terjadi guncangan pada variabel kurs, maka pembiayaan bagi hasil pada bank syariah merespon fluktuatif dalam jangka pendek, namun stabil negatif dalam jangka panjang. Ketika terjadi guncangan pada variabel harga minyak dunia, maka Kredit Produktif bank konvensional merespon fluktuatif dalam jangka pendek, namun stabil negatif dalam jangka panjang. Ketika terjadi guncangan pada variabel kurs, maka pembiayaan bagi hasil pada bank syariah merespon fluktuatif dalam jangka pendek, namun stabil negatif dalam jangka panjang. Hasil Forecast Error Variance Decomposition (FEVD) menunjukkan bahwa, pada bank konvensional NPL memiliki kontribusi terbesar terhadap kredit produktif setelah variabel kredit produktif itu sendiri. Sedangkan pada bank syariah, garfa minya mentah memiliki kontribusi terbesar terhadap pembiayaan bagi hasil.

Temuan pada penelitian ini memberikan rekomendasi bagi para pelaku industri perbankan syariah dan perbankan konvensional untuk dapat memperhatikan faktor-faktor yang dapat meningkatkan kuantitas dan kualitas kredit dan pembiayaaan. Pelaku perbankan konvensional hendaknya memberikan 
perhatian khusus pada NPL (Non Performing Loan), sedangkan pelaku perbankan syariah hendaknya memberikan perhatian khusus atas perubahan yang terjadi pada kondisi makro yaitu harga minyak dunia, karena memiliki kontribusi terbesar dalam pembiayaan bagi hasil. Saran pada penelitian berikutnya untuk menganalisis lebih dalam pengaruh variabel mikro dan makro terhadap pembiayaan bagi hasil di bank syariah maupun kredit pada bank konvensional. Variabel mikro yang dapat diteliti berikutnya adalah ethical behaviour, dan variabel makro dapat menggunakan variabel harga emas dan sebagainya. 


\section{DAFTAR PUSTAKA}

Addury, M. M. (2018). Pengaruh Harga Minyak Dunia dan Nilai Tukar Terhadap Resiko Perbankan Syariah di Indonesia Periode 2007-2018. Wahana Islamika: Jurnal Studi Keislaman, 5(1), 1-20. https://doi.org/10.5281/wahanaislamika.v5i1.39

Afifah, K., Tanjung, H., \& Sukma, A. (2019). Analisis Stabilitas Perbankan Syariah Indonesia Terhadap Guncangan Makroekonomi : Pendekatan Banking Stability Index ( Bsi ). Kasaba: Jurnal Ekonomi Islam, 12(1), 52-66.

Andre, M., \& Nasrudin, N. (2019). Analisis Dampak Guncangan Harga Minyak Mentah Terhadap Makroekonomi Indonesia: Aplikasi Vector Error Correction Mechanism. Media Statistika, 12(1), 13. https://doi.org/10.14710/medstat.12.1.13-25

Ascarya. (2009). Aplikasi Vector Autoregression dan Vector Error Correction Model menggunakan Eviews 4.11. Journal of Economics and Finance, 0, 1-24. https://doi.org/10.1007/s12197-010-9122-2

Ascarya, \& Yumanita, D. (2009). Formulasi Stabilitas Sistem Keuangan Ganda di Indonesia.Working paper Series 11/2009, Jakarta : Pusat Pendidikan dan Studi Kebanksentralan, Bank Indonesia.

Aviliani, A., Siregar, H., Maulana, T. N. A., \& Hasanah, H. (2015). The Impact of Macroeconomic Condition on The Banks Performance in Indonesia. Buletin Ekonomi Moneter Dan Perbankan, 17(4), 379-402. https://doi.org/10.21098/bemp.v17i4.503

Awaluddin, A. (2017). Inflasi Dalam Prespektif Islam (Analisis Terhadap Pemikiran AlMaqrizi). JURIS Jurnal Ilmiah Syariah), 197. https://doi.org/10.31958/juris.v16i2.973

Bank Indonesia. (2011). Peraturan Bank Indonesia Nomor: 13/1/PBI/2011 Tentang Penilaian Tingkat Kesehatan Bank Umum. Peraturan Bank Indonesia, 1-31.

Bank Indonesia. (2015). Peraturan Bank Indonesia Nomor 17/11/PBI/2015 tentang Perubahan atas Peraturan Bank Indonesia Nomor 15/15/PBI/2013 tentang Giro Wajib Minimum Bank Umum dalam Rupiah dan Valuta Asing Bagi Bank Umum Konvensional. Bank Indonesia, 1, 1-5. www.bi.go.id

Basuki, A. T. (2018). Aplikasi Model Var dan Vecm dalam Ekonomi. Fakultas Ekonomi Univ. Muhammadiyah Yogyakarta, 1, 1-41.

Bencivenga, V. R., \& Smith, B. D. (1991). Financial Intermediation and Endogenous Growth. The Review of Economic Studies, 58(2), 195. https://doi.org/10.2307/2297964

Festić, M., \& Bekocombining double acute accent, J. (2008). The banking sector and macroeconomic performance in Central European Economies. Finance a Uver Czech Journal of Economics and Finance, 58(3), 131-151.

Ginting, A. M. (2017). Pengaruh Makroekonomi Terhadap Non Performing Loan (Npl) Di Indonesia: Studi Non Performing Loan Perbankan. Jurnal Ekonomi Dan Kebijakan Publik, 7(2), 159. https://doi.org/10.22212/jekp.v7i2.669

Ichsan, N. (2017). Analisis Pengaruh Ekonomi Makro dan Stabilitas Perbankan Syariah terhadap Pembiayaan Produktif dan Konsumtif pada Perbankan Syariah di Indonesia Periode Januari 2010-Maret 2017. Jurnal Akses, 12, 68-83.

Keeton, W., \& Morris, C. (1987). Why do Banks' Loss Differ? In Economic Review (pp. 321).

Khaliq, A. (2017). Mekanisme Transmisi Goncangan Harga Minyak Dan Harga Pangan Dunia Terhadap Perekonomian Makro Indonesia: Pendekatan Structural Vector 
Autoregressive (Svar). Business Management Journal, 11(2). https://doi.org/10.30813/bmj.v11i2.625

Meitasari, D. A. (2014). Analisis Pengaruh Kredit Konsumtif dan Produktif terhadap Laba Bank Berdasarkan Kelompok Bank. JURNAL ILMIAH ILMU EKONOMI FAKULTAS EEKONOMI DAN BISNIS UNIVERSITAS BRAWIJAYA.

Utari, G. A. D., Arimurti, T., \& Kurniati, I. N. (2012). Pertumbuhan Kredit Optimal dan Kebijakan Makroprudensial untuk Pengendalian Kredit. BI, Buletin Ekonomi Dan Perbankan, 3-36.

Widokartiko, B., Achsani, N. A., \& Beik, I. S. (2016). Dampak Kinerja Internal Dan Kondisi Makro Ekonomi Terhadap Profitabilitas Pada Perbankan. Jurnal Aplikasi Bisnis Dan Manajemen, 2(2), 161-171. https://doi.org/10.17358/jabm.2.2.161

Yudi Setiawan, R., \& Karsinah, K. (2018). Mekanisme Transmisi Kebijakan Moneter dalam Mempengaruhi Inflasi dan Pertumbuhan Ekonomi di Indonesia. Economics Development Analysis Journal, 5(4), 460-473. https://doi.org/10.15294/edaj.v5i4.22183

Yulizar D Sanrego, Z. D. P. (2014). Pengaruh Variabel Makro Dan Mikro Terhadap Npl Perbankan Konvensional Dan Npf Perbankan Syariah. Tazkia Islamic Finance and Business Review, 6(2), 79-104. https://doi.org/10.30993/tifbr.v6i2.53

Yumanita, D., \& Ascarya. (2005). Bank Syariah: Gambaran Umum (Vol. 14, Issue 14). http://www.bi.go.id/id/tentang-bi/bi-dan-

publik/kebanksentralan/Documents/14. Bank Syariah Gambaran Umum.pdf 